\title{
PEMBERDAYAAN MASYARAKAT MELALUI PENDIDIKAN PERENCANAAN DAN PENGELOLAAN KEUANGAN DAN INVESTASI BAGI UMKM DALAM RANGKA PENGEMBANGAN USAHA DAN PENINGKATAN KUALITAS HIDUP KELUARGA
}

\author{
Dede Suryanto ${ }^{1}$ \\ Fibria Indriati Dwi Liestiawati ${ }^{2}$ \\ Ixora Lundia Suwaryono ${ }^{3}$ \\ Pantius Drahen Soeling ${ }^{4}$ \\ 1 Laboratorium Keuangan dan Perbankan, Program Vokasi Universitas Indonesia,d.suryanto@ui.ac.id \\ ${ }^{234}$ Fakultas Ilmu Administrasi Universitas Indonesia
}

Diterima : 1 Desember 2014

Layak Terbit : 3 Januari 2015

\begin{abstract}
Abstrak
Program pemberdayaan masyarakat melalui pendidikan perencanaan dan pengelolaan keuangan dan invertasi bagi UMKM ini bertujuan untuk mengajarkan para pelaku UMKM tentang bagaimana cara membuat perencanaan keuangan mulai dari membuat anggaran, mencari dana tambahan, membuat laporan keuangan serta melakukan investasi bagi pengembangan usaha dan juga melakukan perencanaan keuangan bagi keluarganya. .Program ini dilaksanakan pada para pelaku UMKM di Kota Depok yang tergabung dalam Asosiasi Industri Kreatif Kota Depok sebanyak 30 UMKM. Program yang dilaksanakan dalam bentuk pelatihan dan pendampingan pengelolaan keuangan usaha UMKM. Akhir dari program ini menunjukkan adanya perubahan-perubahan kondisi sebelum dan sesudah dilakukannya program pemberdayaan masyarakat kepada para pelaku UMKM. Saat ini para pelaku UMKM lebih memiliki perilaku positif dalam pengelolaan keuangannya dibandingkan sebelumnya. Hal ini ditandai dengan tersedianya laporan keuangan usaha yang dipisahkan dengan keuangan keluarga. Selain itu juga UMKM mampu mengelola keuangannya dengan lebih bijak yang bertujuan untuk mengembangkan usaha. Dengan adanya program ini, diharapkan seluruh UMKM yang telah mendapatkan pelatihan dan pendampingan menerapkan pengelolaan keuangan yang tepat sesuai dengan kebutuhan dan waktunya secara berkesinambungan dan konsisten.
\end{abstract}

Kata Kunci : UMKM, perencanaan keuangan, pelatihan, pendampingan

\begin{abstract}
. Community Engamenet Program gives the skill of planning and financing education for Small Medium Entreprises (SME), how they make business plan begin budgeting, raising the fund, create financial statement, buseiness development and investing to enhance their wealth of family. This program delivered to $30 \mathrm{SME}$ of Assosiation of Depok Creative Industries (AIKD). Some activities delivered are training and business assistance. The aims of program point out some changes before and after program impelementation. The SME have positive behavior in financing. The success indicators are the SME have financial statement of entrepreises and their family. In otherwise they they can make financial decision wisdom to depelove their entreprises. Hopelly, this program be allowed to to their business needs and can continue and consisten.
\end{abstract}

Key words : SME, financial planning, training and assistance.

\section{PENDAHULUAN}

\section{Latar Belakang}

UMKM memiliki peranan yang krusial dalam pertumbuhan ekonomi di Indonesia. Jumlah UMKM meningkat setiap tahunnya, seperti yang terlihat pada tabel 1 di bawah sejak tahun 2007 - 2012, jumlah UMKM meningkat 2- 2,5\% per tahunnya. Banyaknya jumlah UMKM di Indonesia diharapkan mampu mendorong usaha lokal yang dapat 
mendorong pertumbuhan ekonomi daerah setempat.

UMKM telah terbukti memberikan sumbangan yang signifikan terhadap perekonomian suatu bangsa (Fitriati, 2015). Meskipun diharapkan mampu meningkatkan perekonomian lokal, UMKM dalam kegiatan operasionalnya selalu dihadapkan pada permasalahan-permasalahan klasik antara lain yang terkait dengan sumber daya manusia, pemasaran, produksi dan keuangan. Dikatakan klasik, karena permasalahan tersebut selalu ada dari waktu ke waktu, dan terjadi pada hampir seluruh UMKM, baik yang sudah lama beroperasi maupun yang baru. Di antara permasalahan klasik tersebut, permasalahan yang kerapkali menjadi hambatan adalah permasalahan keuangan (Urata dalam Adiningsih,2009). Analisis aspek finansial mutlak diperlukan untuk menentukan rencna investasi melalui perhitungan biaya dan manfaat yang diharapkan (Lestariyo, 2014). Permasalahan keuangan ini terjadi karena adanya beberapa kesalahan pengelolaan dana yang dilakukan oleh pelaku UMKM. Menurut Johnson (2012) terdapat tujuh kesalahan yang umumnya dilakukan oleh para pelaku UMKM, yaitu: 1) over investasi, 2) tidak menggaji diri sendiri, 3) tidak mempertimbangkan adanya kemungkinan yang terburuh, 4) mencampur aset bisnis dan pribadi, 5) menggunakan kartu kredit pribadi untuk tujuan bisnis, 6) menggunakan kas usaha untuk keperluan pribadi dan 7) tidak memiliki laporan keuangan. Ketujuh kesalahan ini bukan disebabkan karena kesengajaan para pelaku
UMKM untuk melakukannya, melainkan karena ketidaktahuan para pelaku UMKM dalam melakukan perencanaan dan pengelolaan keuangan yang baik dan tepat dan perilaku positif mengatur pendapatan dan pengeluaran usaha dan keluarga. Ketidaktahuan dalam pengelolaan keuangan usaha dan keluarga tidak hanya dialami oleh pelaku UMKM saja tetapi juga oleh seluruh masyakarat Indonesia. Hal ini dibuktikan dengan survei financial quotient (FQ) yang dilakukan oleh citigroup pada tahun 2013 yang menunjukkan bahwa nilai $\mathrm{FQ}$ untuk Indonesia adalah 60,7 poin dari 100 poin (Rizki, 2014). FQ merupakan istilah yang digunakan oleh Citigroup untuk menunjukkan kesadaran akan kondisi keuangan dan kemampuan seseorang dalam memahami pentingnya perencanaan keuangan dan mengimplementasikan tata kelola keuangan dengan baik. Dan berdasarkan beberapa hasil survei menunjukkan hanya 26\% perempuan yang memiliki perencanaan keuangan yang matang (Daulay,2014). Hal ini menunjukkan bahwa belum adanya kesadasaran dan kemampuan dari masyarakat Indonesia dalam hal perencanaan dan pengelolaan keuangan. Berdasarkan data ini maka program pendidikan perencanaan dan pengelolaan keuangan dan investasi bagi pelaku UMKM penting untuk dilaksanakan dalam rangka meningkatkan kesadaran dan kemampuan pelaku UMKM untuk melakukan perencanaan keuangan yang baik dan tepat sesuai dengan kebutuhan dan kemampuannya. Perencanaan keuangan ini bukan hanya ditujukan untuk pengembangan usahanya saja tetapi juga 
untuk meningkatkan kualitas hidup keluarga. Program Pemberdayaan Masyarakat Melalui Pendidikan Perencanaan Dan Pengelolaan Keuangan dan Investasi Bagi Pengembangan Usaha dan Keluarga UMKM merupakan suatu program pelatihan dan pendampingan bagi UMKM untuk merencanakan dan mengelola keuangan usahanya.

Pada program ini, para pelaku UMKM diajarkan bagaimana cara membuat perencanaan keuangan mulai dari membuat anggaran, mencari dana tambahan, membuat laporan keuangan serta melakukan investasi bagi pengembangan usaha dan juga melakukan perencanaan keuangan bagi keluarganya.
Untuk mengatasi permasalahan ini maka perlu dilakukan suatu program pemberdayaan masyarakat berupa pendidikan perencanaan dan pengelolaan keuangan dan investasi bagi UMKM dalam rangka pengembangan usaha dan peningkatan kualitas hidup keluarga. Program yang bukan hanya memfokuskan pada pembuatan laporan keuangan saja tetapi juga menfokuskan pembuatan rencana bisnis dan perencanaan keuangan sehingga UMKM dapat mengukur kemajuan usaha dan mengembangkan usahanya. Rencana bisnis merupakan suatu alat yang dirancang untuk menemukan dan mengeksplorasi peluangpeluang baru Echdar 2013).

Tabel 1

Perkembangan UMKM 2007 - 2012

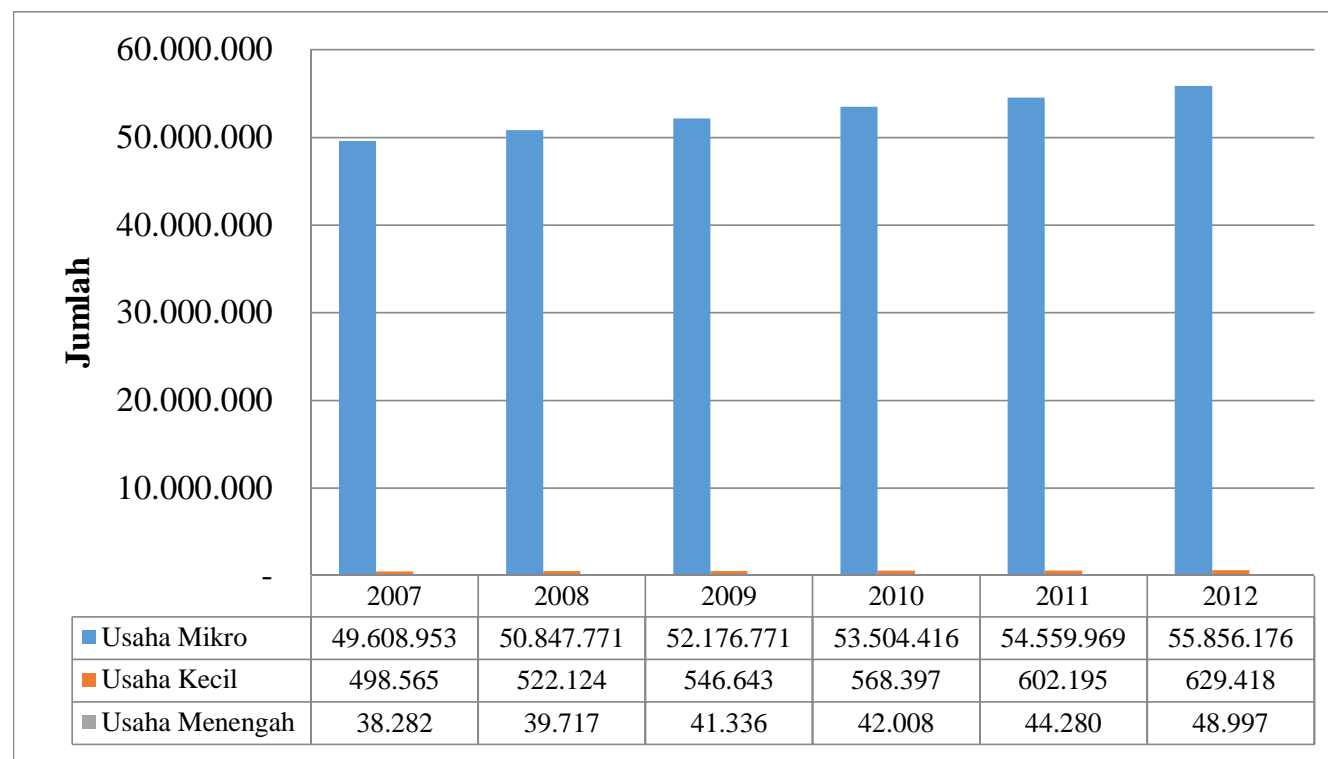

Sumber: depkop.go.id, 2014

Program ini mengajarkan bagimana para pelaku UMKM melakukan suatu perencanaan keuangan yang baik dan tepat (tepat waktu dan tepat tempat).
Program Pemberdayaan Masyarakat Melalui Pendidikan Perencanaan Dan Pengelolaan Keuangan dan Investasi Bagi Pengembangan Usaha dan Keluarga UMKM merupakan suatu program pelatihan dan pendampingan 
bagi UMKM untuk merencanakan dan mengelola keuangan usahanya. Pada program ini, para pelaku UMKM diajarkan bagaimana cara membuat perencanaan bisnis dan perencanaan keuangan. Perencanaan keuangan mulai dari membuat anggaran, mencari dana tambahan, membuat laporan keuangan serta melakukan investasi bagi pengembangan usaha dan juga melakukan perencanaan keuangan bagi keluarganya. Program ini mengajarkan bagimana para pelaku UMKM melakukan suatu perencanaan keuangan yang baik dan tepat (tepat waktu dan tepat tempat) sesuai dengan kebutuhan usaha dan rencana pengembangan bisnis. Peningkatan kemampuan keuangan lebih jauh akan mendukung kekuatan daya saing UMKM (Barney, 2007)

Program ini dilaksanakan pada para pelaku UMKM di Kota Depok yang tergabung dalam Asosiasi Industri Kreatif Kota Depok. Program yang dilaksanakan dalam bentuk pelatihan dan pendampingan pengelolaan keuangan usaha UMKM. Untuk pelatihan, digunakan teknik partisipatif, dimana para peserta akan turut ambil bagian dalam diskusi kelompok, berbagi pengalamanan baik positif maupun negatif dan menggali pelajaran baru bersama. Dan setelah dilakukan pelatihan, maka peserta diminta untuk mengimplementasikan yang telah dipelajari selama pelatihan dengan didampingi oleh para pengabdi dan beberapa mahasiswa.

\section{METODE}

Dalam pelaksanaan program ini dibagi menjadi tiga tahapan, yaitu persiapan, pelaksanaan dan evaluasi. Perincian setiap tahapan adalah sebagai berikut:

1. Tahapan persiapan merupakan tahapan awal dengan pertama-tama melakukan survei lapangan, melakukan identifikasi permasalahan awal dengan melakukan wawancara mendalam dengan mitra, penelusuran data sekunder dan perencanaan jadwal pelatihan dan pendampingan.

2. Tahap Pelaksanaan Kegiatan Pelaksanaan kegiatan adalah sebagai berikut:

a. melakukan perkenalan terhadap pelaku UMKM baik yang tergabung dalam asosiasi industri kreatif Depok

b. Identifikasi masalah di lapangan terkait :

1) perilaku pengelolaan keuangan usaha keluarga UMKM

2) potensi sumber daya ekonomi yang dapat dikembangkan

3) kebutuhan dan harapan keluarga untuk meningkatkan penghasilan

c. Merumuskan konten, teknik pelatihan dan pembekalan kepada mahasiswa sebagai fasilitator pelatihan dan pendampingan

d. Mengkomunikasikan rencana dan jadwal kegiatan pelatihan

e. Melakukan pelatihan sesuai jadwal yang telah disusun

3. Pelaksanaan Pelatihan (Workshop)

a. Workshop dilakukan dengan menggunakan modifikasi modul perencanaan keuangan dan investasi yang dikeluarkan 1oleh FPSB (Financial Planning Standar Board). 
b. Modul ini dimodifikasi karena modul yang dikeluarkan oleh FPSB adalah modul perencanaan keuangan dan investasi untuk keluarga, sehingga untuk UMKM diperlukan beberapa penyesuaian dan penyempurnaan

c. Workshop akan dilakukan selama dua hari mengingat pelaku UMKM biasanya tidak dapat meninggalkan usaha dalam jangka waktu yang lama dengan peserta kurang lebih 30 orang yang berasal dari anggota asosiasi Industri Kreatif Kota Depok.

d. Pembicara dalam workshop tidak hanya dari pengabdi saja tetapi juga dari pihak luar yang berkompeten seperti bank, manajer investasi dan lembaga pembiayaan lainnya.

4. Pelaksanaan Pendampingan dan Evaluasi Pendampingan diberikan sebanyak $3 \quad \mathrm{x}$ setelah pelatihan. Pendampingan ini merupakan supervisi bagi para peserta pelatihan dalam mengaplikasikan pengetahuan dan keterampilan yang diperoleh. Supervisi dimaksudkan untuk menilai kesesuaian aplikasi dengan keterampilan dan pengetahuan yang diberikan selama pelatihan.

Pada akhir program diharapkan para pelaku UMKM dapat melakukan perencanaan dan pengelolaan keuangan seperti membuat anggaran pemasukan dan pengeluaran baik untuk usaha maupun keluarga, membuat pilihan-pilihan pengembangan produk dan secara kreatif memilih investasi yang menguntungkan bagi usahanya. Dengan adanya program ini diharapkan pelaku
UMKM dapat mengoptimalkan penggunaan keuangan dam memberdayakan keuangan untuk meningkatkan kemampuan ekonominya. Program ini mampu meningkatkan kesadaran dan kemampuan para pelaku UMKM untuk mengatasi permasalahan keuangan yang dihadapinya dan mencari alternatif penyelesaian yang terbaik.

\section{HASIL DAN PEMBAHASAN}

Dalam pelaksanaan program ini dibagi menjadi tiga tahapan, yaitu persiapan, pelaksanaan dan evaluasi. Perincian setiap tahapan adalah sebagai berikut:

1. Tahapan persiapan merupakan tahapan awal dengan pertama-tama melakukan survei lapangan, melakukan identifikasi permasalahan awal dengan melakukan wawancara mendalam dan diskusi kelompok terarah dengan dengan mitra, penelusuran data sekunder dan perencanaan jadwal pelatihan dan pendampingan.

\section{Tahap Pelaksanaan Kegiatan}

Pelaksanaan kegiatan adalah sebagai berikut:

a. melakukan perkenalan terhadap pelaku UMKM yang tergabung dalam asosiasi industri kreatif depok yang telah dilaksanakan pada tanggal 11 Agustus 2014, di FISIP UI

b. Identifikasi masalah di lapangan terkait melalui diskusi kelompok terarah yang dilaksanakan di ruang rapat Departemen Ilmu Administrasi FISIP UI, tanggal 16 Desember 2014. 
Adapun permasalahan yang dihadapi oleh para UMKM meliputi

a. Pengelolaan keuangan usaha

b. Akses kepada pembiayaan yang terbatas

c. Akses pada pemasaran yang terbatas

d. Single fighter dalam usaha sehingga harus menjadi orang yang multi-tasking.

e. Kebutuhan dan harapan keluarga untuk meningkatkan penghasilan

f. Harapan usaha dapat berkembang dan diwariskan kepada anak dan cucu

c. Mengkomunikasikan rencana dan jadwal kegiatan pelatihan kepada asosiasi

d. Menyusun modul pelatihan dengan topic sebagai berikut:

1. Pengelolaan Keuangan Usaha

2. Pemasaran

3. Sumber Daya Manusia

4. Business Model Canvas (Model Bisnis Kanvas)

5. Pembiayaan Usaha

6. Rencana Bisnis dan Rencana Anggaran

\section{Pelaksanaan Pelatihan}

a. Pelatihan dilakukan pada tanggal 17 18 Februari 2015 yang bertempat di Gedung G FISIP UI, Ruang G. 303.

b. Pelatihan dilakukan selama dua hari, dari pukul $09.00-17.00$ WIB. Berdasarkan anggaran, pelatihan seharusnya diikuti oleh 30 peserta, namun karena animo dari anggota AIKD besar, maka jumlah peserta meningkat menjadi 50 orang melebihi kuota.

c. Pelatihan dilakukan dengan menggunakan modul yang dibuat oleh tim pengabdi masyarakat yang disesuaikan dengan permasalahan dan kebutuhan dari UMKM.

d. Workshop akan dilakukan selama dua hari mengingat pelaku UMKM biasanya tidak dapat meninggalkan usaha dalam jangka waktu yang lama dengan peserta kurang lebih 30 orang yang berasal dari anggota asosiasi Industri Kreatif Kota Depok.

e. Pembicara dalam workshop tidak hanya dari pengabdi saja tetapi juga dari dosen FISIP UI yang memiliki kompetensi untuk memberikan pelatihan tentang rencana bisnis.

4. Pelaksanaan Pendampingan dan Evaluasi Setelah pelatihan mengenai pengelolaan keuangan telah dijalankan, maka tahapan selanjutnya dilaksanakan pendampingan. Pendampingan diberikan sebanyak $3 \quad \mathrm{x}$ setelah pelatihan. Pendampingan dilakukan selama 3 bulan (Awal Maret - Akhir Mei 2015). Pendampingan ini merupakan supervisi bagi para peserta pelatihan untuk mengimplementasikan pengetahuan dan keterampilan yang diperoleh selama pelaihan. Supervisi dimaksudkan untuk menilai kesesuaian aplikasi dengan keterampilan dan pengetahuan yang diberikan selama pelatihan. 


\section{PEMBERDAYAAN MASYARAKAT MELALU PENDIDIKAN PERENCANAAN DAN PENGELILAAN KEUANGAN DAN INVESTASI BAGI \\ UMKM DALAM RANGKA PENGEMBANGAN USAHA DAN PENINGKATAN KLALITAS HIDUP KELUARGA \\ Dede Suryanto , Fibria Indriati Dwi Liestiawati , Ixara Lundia Suwaryono, Pantius Drahen Saeling \\ Volume 3 Namar I ,p 31-4|}

Hasil dari pendampingan ini, diharapkan pelaku UMKM memiliki perencanaan keuangan yang dimulai dari adanya laporan keuangan yang disusun secara baik dan benar, serta mengikuti kaidah akuntansi yang tepat.

Pendampingan tidak diberikan kepada seluruh UMKM yang ikut dalam pelatihan, karena adanya keterbatasan waktu dan biaya dari para pengabdi, maka dipilih UMKM yang benar-benar siap dan memiliki komitmen untuk melaksanakan dan mengimplementasikan materi-materi yang telah dipelajari. Dari 30 UMKM yang mengikuti pelatihan, maka yang didampingi 24 UMKM. Pemilihan UMKM ini didasarkan pada kriteria sebagai berikut:

a. UMKM memiliki data awal keuangan

b. UMKM memberikan data awal keuangan yang menjadi check-up awal bagi tim pengabdi

c. UMKM memiliki waktu dan komitmen untuk ikut dalam pendampingan, sebab ada juga UMKM yang hanya mau mengikuti pelatihan tetapi tidak memiliki waktu untuk pendampingan.

Proses pendampingan dibagi menjadi 3 (tiga) batch, hal ini dilakukan karena adanya keterbatasan jumlah pengabdi dan mahasiswa. Dalam proses pendampingan, pengabdi dan mahasiswa mendatangi rumah UMKM sesuai dengan waktu yang dijanjikan. Adapun rincian dari $3 \mathrm{x}$ pertemuan adalah sebagai berikut:

a. Pertemuan Pertama; Pertemuan pertama pendampingan adalah merupakan tahap pengidentifikasian permasalahan UMKM secara individual. Tujuan dari identifikasi ini adalah untuk mendapatkan gambaran yang lebih tepat mengenai program pendampingan yang diperlukan oleh para UMKM (Taylor Made).

Pada pertemuan pertama, rata-rata waktu pertemuan 1-2 jam. Pada tahap ini, pengabdi juga memperkenalkan mahasiswa yang akan mendampingi selama untuk pertemuan kedua dan ketiga. Selain identifikasi masalah, tim juga meminta data awal keuangan dari usaha.; b. Pertemuan Kedua

Pertemuan kedua dari pendampingan adalah tahap penyusunan data awal keuangan menjadi laporan keuangan sederhana yang sesuai dengan kaidah akuntansi. Pertemuan kedua ini dilakukan oleh para mahasiswa yang mencoba memberikan penjelasan pengelolaan keuangan kepada para pemilik usaha dan juga staf pembukuannya.

\section{c. Pertemuan Ketiga}

Pertemuan ketiga adalah tahap penyusunan laporan keuangan sederhana yang dapat dipergunakan untuk keperluan pemilik, kepentingan perbankan dan juga untuk pelaporan pajak. Pada pertemuan ketiga, para UMKM diperkenalkan pada program akuntansi untuk dapat dipergunakan selanjutnya.

\section{Hasil Pencapaian Program}

Outcome yang diharapkan pada akhir program adalah para pelaku UMKM dapat melakukan perencanaan dan pengelolaan keuangan seperti membuat anggaran 


\section{PEMBERDAYAAN MASYARAKAT MELALU PENDIDIKAN PERENCANAAN DAN PENGELULAAN KELANGAN DAN INVESTASI BAGI \\ UMKM DALAM RANGKA PENGEMBANGAN USAHA DAN PENINGKATAN KLALITAS HIDUP KELUARGA \\ Dede Suryanta , Fibria Indriati Dwi Liestiawati , Ixara Lundia Suwaryana , Pantius Drahen Saeling \\ Volume 3 Namar I ,p 31-4|}

pemasukan dan pengeluaran baik untuk usaha maupun keluarga, membuat pilihan-pilihan pengembangan produk dan secara kreatif memilih investasi yang menguntungkan bagi usahanya. Dengan adanya program ini diharapkan pelaku UMKM dapat mengoptimalkan penggunaan keuangan dam memberdayakan keuangan untuk meningkatkan kemampuan ekonominya. Program ini mampu meningkatkan kesadaran dan kemampuan para pelaku UMKM untuk mengatasi permasalahan keuangan yang dihadapinya dan mencari alternatif penyelesaian yang terbaik. Dengan demikian perubahan yang terjadi adalah setelah mengikuti program ini, permasalahan UMKM khususnya yang terkait dengan permasalahan keuangan yang terkait dengan permasalahan pengelolaan dapat diminimalisir bahkan ditiadakan.

Untuk melihat keberhasilan dari program, maka dilakukan evaluasi dari setiap kegiatan. Untuk kegiatan pelatihan, akan dilakukan evaluasi reaksi, learning dan result. Indikator keberhasilan dari pelatihan adalah:

a. Peserta mampu membuat rencana bisnis melalu kanvas bisnis model (BMC) yang memuat mengenai perencanaan usaha selama 5 tahun

b. Peserta mampu melakukan check-up keuangan usaha

c. Peserta memiliki data awal keuangan usaha.

Sedangkan untuk kegiatan kedua, pendampingan, indikator keberhasilan yang akan diukur adalah: a. terdapatnya dokumen perencanaan keuangan dari UMKM;

b. Terdapat laporan keuangan sederhana UMKM.

Seluruh indikator keberhasilan yang tertera di atas dapat dicapai dalam program ini. Adapun evaluasi yang dilakukan terhadap 24 orang peserta dalam program ini yaitu mencakup kebutuhan yang dirasakan secara umum oleh UMKM dengan rata-rata nilai 9,34, ketepatan materi yang diberikan dengan rata-rata nilai 8,89 , peralatan dan perlenngkapan pendukung kegiatan 8,78, proses pelaksanaan kegiatan 9,12, dan manfaat yang dirasakan memperoleh rata-rata nilai 8,89 .

Berdasarkan evaluasi lisan yang dilakukan dengan peserta, maka dapat dilihat bahwa peserta program pengabdian masyarakat merasakan mendapatkan manfaat dari adanya program ini.

\section{Perubahan-perubahan Setelah dan}

\section{Sebelum Program}

Program pengabdian masyarakat ini telah membawa perubahan-perubahan baik bagi UMKM. Perubahan-perubahan tersebut dilakukan melalui serangkaian kegiatan antara lain wawancara, focus group discussion, pelatihan dan pendampingan. Adapun perubahan-perubahan yang dilakukan sebagai berikut:

1. Kondisi sebelum kegiatan :

a. Belum mengetahui realitas kenyataan yang dihadapi oleh para pelaku UMKM

b. Para pelaku UMKM belum pernah melakukan cek up keuangan usaha 
c. Para pelaku UMKM tidak melakukan rencana bisnis dalam menjalankan usahanya

d. Para pelaku UKM tidak melihat bisnisnya secara terintegrasi

e. Para pelaku UKM tidak menyadari pentingnya laporan keuangan yang baik dan sesuai kaidah akuntansi

f. Para pelaku UMKM tidak memiliki laporan keuangan usaha sesuai dengan kaidah akuntansi

g. Para pelaku UMKM tidak pernah menggunakan software akuntansi dalam pembuatan laporan keuangan

2. Kondisi setelah kegiatan:

a. Terdapat inventarisasi permasalahan yang dihadapi oleh pelaku UMKM di Kota Depok

b. Terdapat cek up keuangan usaha yang menunjukkan tingkat kesehatan keuangan perusahaan

c. Para pelaku memiliki visi, misi dan sasaran pengembangan usaha untuk 5 tahun ke depan

d. Pelaku UMKM merumuskan model bisnisnya dalam model bisnis kanvas

e. Pelaku UMKM menyadari manfaat laporan keuangan terutama dalam hal perhitungan pajak, karena adanya aturan perpajakan yang baru

f. Para pelaku UMKM memiliki laporan keuangan usaha yang terdiri dari laporan laba rugi, neraca dan laporan arus kas g. Para pelaku UMKM menggunakan software akuntansi "Zahir" dalam proses pendampingan.

\section{Mitra dan Sustainability}

Mitra yang terlibat dalam program ini adalah Asosiasi Industri Kreatif Kota Depok (AIKD) yang beranggotakan para UMKM yang memproduksi produk-produk kreatif. Seluruh anggota AIKD juga merupakan anggota asosiasi UMKM Kota Depok. Alasan pemilihan AIKD sebagai mitra adalah anggota asosiasi merupakan UMKM yang bertindak sebagai produsen, dan memiliki data yang lebih akurat dibandingkan dengan data yang terdapat pada Dinas Koperasi, UMKM dan Pasar Kota Depok. Selain bermitra dengan AIKD, program ini juga bermitra dengan Dinas koperasi, UMKM dan pasar Kota Depok selaku lembaga pemerintah yang berwenang melakukan pembinaan terhadap UMKM.

Program pelatihan dan pendampingan terhadap 30 UMKM di Kota Depok berwujud sebagai TOT (Training of Trainers) sehingga diharapkan setelah program ini berakhir, program ini dapat dilanjutkan dan disebarkan untuk pelaku UMKM lainnya yang nantinya tidak mengikuti. Melalui metode workshop diharapkan peserta menjadi lebih mengerti dan mampu menjelaskan kepada rekan UMKM lainnya. Sehingga diharapkan program ini dapat berlanjut melalu efek snowball dari anggota ke anggota UMKM yang lain. Dan bila terdapat kesulitan, mitra dalam hal ini AIKD - masih dapat menghubungi tim pengabdi.Selain itu ILO 


\section{PEMBERDAYAAN MASYARAKAT MELALU PENDIDIKAN PERENCANAAN DAN PENGELILAAN KEUANGAN DAN INVESTASI BAGI \\ UMKM DALAM RANGKA PENGEMBANGAN USAHA DAN PENINGKATAN KUALITAS HIDUP KELUARGA \\ Dede Suryanta , Fibria Indriati Dwi Liestiawati , Ixara Lundia Suwaryana , Pantius Drahen Saeling \\ Volume 3 Namar I ,p 3|-4|}

melalui lembaga keuangan mikro, dengan program tahunan yang terkait dengan UMKM dapat menjadi alternatif pendanaan untuk melanjutkan kegiatan ini.

\section{PENUTUP}

\section{Simpulan}

Berdasarkan program pengabdian masyarakat, maka dapat disimpulkan bahwa:

a. Pengetahuan dan pemahaman pelaku UMKM terhadap pengelolaan keuangan usaha menjadi meningkat.

b. Para pelaku UMKM dapat melakukan pengelolaan keuangan usaha lebih profesional lagi seiring dengan impian akan adanya peningkatan usaha

\section{Saran}

Mengingat besarnya manfaat program pengabdian masyarakat ini, maka selanjutnya diperlukan: a. Mengadakan pendampingan pengelolaan keuangan usaha lebih luas lagi tidak hanya pada UMKM yang berada di Depok tetapi juga di tempat lainnya.

b. Adanya kesinambungan dan monitoring program pasca pengabdian ini sehingga para pelaku UMKM benar-benar dapat mengimplementasikan pengelolaan keuangan yang baik dan benar.

\section{Ucapan terima kasih}

Selama pelaksanaan kegiatan tim pengabdi banyak memperoleh masukan dan dukungan dari berbagai pihak. Terima kasih kepada DRPM yang telah memberikan kesempatan berharga, Dinas Koperasi,UKM dan Pasar Depok, Asosiasi Industri Kreatif Depok, PT Zahir Accounting Int'l dan tidak lupa untuk Program Vokasi dan FISIP UI.

\section{DAFTAR PUSTAKA}

Buku :

Barney, Jay B (2007), Gaining and Sustaining Competitive Advantage, New York : Pearson Prrentice Hall

Echdar Saban, Manajemen Entrepreneurship : Kiat Sukses menjadi Wirausaha, CV Andi Offset, Yogyakarta, 2013

Fitriati, Rahma, Menguak Daya Saing UMKM Industri Kreatif, Sebuar Riset Tindakan berbasis SSM, Yayasan Pustaka Obor Indonesia, Jakarta 2015

Lestariyo, Budi, Wirausaha Mandiri : Dasar-dasar Pengembangan SDM dalam Bisnis dan Kepemimpinan, Penerbit Nuansa Cendekia, Bandung, 2014.

\section{Internet :}


Adiningsih, Sri.(2009).Regulasi dalam revitalisasi usaha kecil dan menengah di Indonesia. BaliSeminar. 10 Januari 2009.http://lfip.uscschooloflaw.org/english/pdf/bali-seminar/regulasi dalam revitalisasi-sri adiningsih.pdf

Johnson, Eric.(2012).Seven Money Mistakes Young Entrepreneurs Make. http://www.entrepreneur.com/article/220116

Daulay, Lukmanul Hakim. (2014).Hanya 25\% Perempuan Indonesia Punya Rencana Keuangan Matang.Bisnis Indonesia. 23 April 2014

Rizki, Januar. (2014). Pengetahuan Keuangan Masyarakat Indonesia Meningkat, swa.co.id, 25 Februari 2014. http://swa.co.id/business-research/pengetahuan-keuangan-masyarakat-indonesiameningkat

Sugis, Shofiatu Rahmah. Kartika, Lindawati. (2014).Model Peningkatan Kinerja Usaha Kecil Menengah melalui Pengembangan Modal Insani dan Modal Sosial (Studi kasus UKM Makanan dan Minuman di Kota Depok).

http://www.slideshare.net/ShofiatuRahmahSugis/jurnal-model-peningkatan-kinerja-usahakecil-menengah-melalui-pengembangan-modal-insani-dan-modal-sosial

\section{Sumber :}

Depkop.go.id, 2014, Data UMKM 2007 - 2014

Dinas Koperasi, UMKM dan Pasar, 2011, Survey UMKM Kota Depok 